\title{
ANALISIS PERSENTASE INDEKS KADAR CPO (CRUDE PALM OIL) DI PTPN III AEK NABARA KECAMATAN BILAH HULU.
}

\author{
Yusmaidar Sepriani, Dede Suhendra dan Zulfikar Ritonga \\ Program Studi Agroteknologi, Sekolah Tinggi Ilmu Pertanian Labuhanbatu \\ Email : seprie87@gmail.com
}

\begin{abstract}
Percentage analysis of CPO (Crude Palm Oil) index in PKS PTPN III Aek Nabara Selatan Kecamatan Bilah upstream. The results of this study by presenting the data using IBM SPSS 20.0 can be concluded the results of multiple linear regression calculation declared the amount of CPO production to the influence of free fatty acids, water content, impurity content in PKS PTPN III Aek Nabara Selatan Kecamatan Bilah Hulu. This shows the results of a strong and positiveget value of 0.8 close to 1 it means to have the effect of the amount of CPO production in PKS PTPN III Kebun Aek Nabara Selatan with the value of $R$-Square 0.008 can be interpreted that the influence of Fatty Acids Free, Water Content, Impurities concentration to the production amount of $8 \%$ (0.8) while the remaining 98.2\% is influenced by other models not included in the test.
\end{abstract}

Keywords : CPO, impurity level, water content

\section{PENDAHULUAN}

Kelapa sawit merupakan sumber minyak nabati yang penting di samping kelapa, kacang-kacangan, jagung, bunga matahari dan lain sebagainya. Komoditas kelapa sawit merupakan komoditas yang sangat menjanjikan karena minyak kelapa sawit mampu menghasilkan berbagai hasil industri hilir yang dibutuhkan manusia. Mutu minyak kelapa sawit mempunyai arti yang sangat penting karena mutu minyak kelapa sawit akan menjamin sebuah PKS (Pabrik Kelapa Sawit) untuk dapat bersaing dengan PKS lain (Tim Bina Karya Tani, 2009).

Minyak kelapa sawit merupakan salah satu komoditi yang sangat penting disamping migas yang juga memiliki nilai ekspor yang cukup baik. Oleh sebab itu, perlu adanya pengawasan untuk menjaga mutu maupun kuantitas komoditi tersebut. Minyak kelapa sawit yang dihasilkan tersebut haruslah didukung dengan standar mutu yang ditetapkan oleh SNI. Dengan mutu yang baik, produk akan lebih mudah diterima konsumen yang pada umumnya merupakan industri pengolahan produk tersier minyak kelapa sawit dengan harga yang sesuai dan mampu bersaing dengan minyak nabati jenis lainnya seperti minyak kedelai, minyak jagung dan lain sebagainya. Disamping itu, hasil produksi minyak kelapa sawit tersebut harus dapat bertahan lama 
menyesuaikan permintaan konsumen. Beberapa kriteria minyak kelapa sawit yang diperlukan adalah memiliki warna kemerahan, rasa dan bau yang enak, dapat disimpan dalam jangka yang lama, mudah dimurnikan dan tingkat hidrolisa pada pembentukan Asam Lemak Bebas (ALB) yang dihasilkan rendah. Untuk itu perlu dilakukan analisa mutu produksi dengan cara menganalisa kadar ALB, air dan kotoran dalam minyak kelapa sawit tersebut apakah telah sesuai dengan mutu yang ditetapkan sehingga dapat bersaing di pasar internasional. Untuk memperoleh hasil yang maksimal baik mutu maupun kuantitas maka dalam pengolahan kelapa sawit di pabrik mulai dari tahap proses pengolahan sampai penimbunan harus memperhatikan dan menjaga standar mutu yang berlaku pada perusahaan tersebut (Tim Standarisasi Pengolahan Kelapa Sawit, 1997).

Industri kelapa sawit merupakan industri primadona Indonesia dari sektor nonmigas, hal ini dibuktikan dengan besarnya devisa yang dikontribusikan dari sektor industri ini. Indonesia merupakan negara pengekspor CPO (Crude PalmOil) terbesar ke dua di dunia. Ekspor minyak sawit CPO pertama dari Indonesia tercatat pada tahun 1919 dengan volume 576 ton. Volume ini meningkat terus seiring dengan peningkatan areal perkebunan kelapa sawit Indonesia, sehinggapada tahun 1937 pasar industri produksi $\mathrm{CPO}$ Indonesia mencapai $40 \%$ dari total produksi CPO dunia. Laju perkebunan rakyat Indonesia meningkat dari sekitar 1.1 juta ha menjadi 3.3 juta ha tahun 2010. Perkebunan negara juga meningkat dari 588 ribu ha tahun 2000 menjadi menjadi 616 ribu ha tahun 2010. Demikian juga perkebunan swasta meningkat dari 2.4 juta ha tahun 2000 menjadi 3.9 juta ha tahun 2010. Sehingga total, perkebunan kelapa sawit Indonesia meningkat dari 4.1 juta ha tahun 2000 menjadi 7.8 ha tahun 2010 atau hampir dua kali lipat dalam 10 tahun. Peningkatan produksi CPO lebih meningkat lagi yakni meningkat hampir 3 kali lipat dalam 10 tahun yakni dari 7 juta ton tahun 2000 menjadi 20 juta ton pada tahun 2010 (Sipayung, 2012).

Tingginya angka produksi $\mathrm{CPO}$ Indonesia maka industri minyak kelapa sawit terus melakukan perbaikan mutu agar cemaran logam yang terkandung dalam minyak sawit dapat diperkecil jumlahnya dan tidak melewati Standar Nasional Indonesia (SNI) (Simarmata, 1998).

Di dalam industri minyak kelapa sawit, ketersediaan TBS kelapa sawit sebagai bahan baku minyak kelapa sawit harus dipertahankan, kuantitas dan kualitasnya. Terdapat tiga subsistem utama dalam kegiatan pascapanen, yakni pemanenan, pengangkutan dan pengolahan. Di antara ketiganya terdapat saling keterkaitan, satu hambatan didalam satu subsistem berpengaruh terhadap kinerja subsitem yang lain. Misalnya hambatan di pengangkutan TBS dari kebun ke Pabrik Minyak Kelapa Sawit (PMKS) menyebabkan keterlambatan yang kemudian mengganggu pengolahan minyak, kapasitas pengolahan, dan kualitas akhir minyak kelapa sawit (Pahan, 2006).

Secara alamiah, kadar ALB setelah TBS dipanen akan meningkat $0,1 \%$ setiap 24 jam (Lubis, 1992), di sisi lain kadar ini tidak boleh lebih dari 2-3\% pada saat masuk proses di PMKS (Mangoensoekarjo \& Tojib, 
2008). Penurunan kualitas ini akan lebih cepat yang disebabkan oleh penanganan secara fisik. Sementara itu proses panen dan angkut tidak bisa sepenuhnya dihindarkan dari perlakuan fisik. Kerusakan buah pada tahap panen-angkut akan menjadi pemicu penurunan kualitas di tahap berikutnya

\section{METODOLOGI PENELITIAN}

\section{Waktu dan Tempat}

Penelitian dilaksanakan pada bulan Maret dan April 2018 untuk mengetahui mutu CPO yang telah diolah dan akan dikirim atau dipasar oleh PKS perharinya.Lokasi Penelitian dilaksanakan di Laboratorium PKS PT. Perkebunan Nusantara III Aek Nabara Selatan Kecamatan Bilah Hulu Kabupaten Labuhan Batu. Sampel diambil dari Storage atau tangki penimbunan CPO.

\section{Bahan dan Alat}

Alat yang digunakan adalah botol sampel buret $10 \mathrm{ml}$ erlenmeyer $250 \mathrm{ml}$, gelas ukur $25 \mathrm{ml}$, oven, desikator, beaker glass, corong, botol semprot, kertas saring dan neraca analitik digital. Bahan yang digunakan adalah sampel minyak CPO, Indikator Thymol Blue, iso hexane, larutan $\mathrm{KOH} 0.1044 \mathrm{~N}$ dan alkohol $96 \%$.

\section{Prosedur Percobaan}

1. Analisa Kadar Asam Lemak Bebas (ALB) (Metode titrasi asama basa)
a. Ditimbang sampel minimal $3 \mathrm{~g}$ dengan neraca analitik digital.
b. Dimasukkan ke dalam Erlenmeyer 250 $\mathrm{ml}$.
c. Dimasukkan $10 \mathrm{ml}$ hexane.

karena memar atau luka yang diderita buah akan mempercepat kenaikan kadar ALB. Kadar ALB akan meningkat cepat jika struktur sel rusak/pecah, misalnya oleh karena impak fisik (Yuwana et al., 2009).

d. Ditambahkan $20 \mathrm{ml}$ alkohol $96 \%$ dan 3 tetes thymol blue.

e. Dititrasi dengan larutan $\mathrm{KOH} 0.1044 \mathrm{~N}$ sampai larutan berwarna kehijauhijauan.

Rumus:

$\% A L B=\frac{\text { Jumlah titrasi } \times 0.1044 \times 25.6}{\text { sampel minyak }}$

\section{Analisa Kadar Air}

a. Keringkan beaker glass dalam oven selama 15 menit pada suhu $105.5^{\circ} \mathrm{C}$

b. Biarkan dingin dalam desikator selama 15 menit. Timbang glass kosong.

c. Masukkan sampel minimal $11 \mathrm{~g}$ ke dalam beaker glass.

d. Dipanaskan di hotplate sampai beruap dengan suhu $100^{\circ} \mathrm{C}$

e. Didinginkan sampel dalam desikator selama 30 menit.

f. Ditimbang (beaker + sampel) menggunakan neraca analitik.

g. Dihitung kadar airnya.

Rumus:

Kadar air (\%)

$=\frac{\text { B. Sampel setelah dipanasi } \%-100}{\text { sampel sebelum dipanasi }}$

\section{Analisa Kadar Zat Pengotor (Metode} Gravimetri)

a. Timbang sampel CPO minimal $11 \mathrm{~g}$ didalam beaker glass

b. Timbang kertas saring (whatman) 
c. Letakkan kertas saring pada erlenmeyer, tuangkan minyak dan cuci dengan Hexane sampai minyak terlarut semua.

d. Keringkan kertas saring tersebut dalam oven pada suhu $105.5^{\circ} \mathrm{C}$ selama 30 menit.

e. Didinginkan dalam desikator selama 15 menit.

f. Timbang kertas saring yang telah diovenkan untuk mengetahuiberat keringnya (A).

Rumus:

$\%$ kotoran

$=\frac{B . \text { Kotoran }(\%)}{\text { sampel minyak setelah dipanasi }}$

\section{Metode Analisis Data}

Data yang didapat dari hasil pengamatan diidentifikasi dan selanjutnya diolah dengan menggunakan IBM SPSS Statistic 20.0 dapat membantu pengolahan data pengujian hipotesis berbagai uji, analisis data statistika, uji f, uji non parametric, uji t, analisis regresi dan lainlain.

\section{Depenisi Variabel Penelitian}

Variabel penelitian adalah suatu objek penelitan atau yang menjadi titik perhatian dalam suatu penelitian yang ditetapkan dengan jelas sebelum pengumpulan data pada penelitian.

Variabel penelitian dalam penelitian adalah sebagai berikut:

a. Jumlah produksi PKS (Y) yaitu jumlah produksi CPO yang dhasilkan oleh PKS dalam satuan $(\mathrm{Kg})$.

b. ALB $\left(\mathrm{X}_{1}\right)$ adalah nilai hasil analisis pada PKS dalam satuan (\%).

c. AIR $\left(\mathrm{X}_{2}\right)$ adalah nilai hasil analisis pada PKS dalam satuan (\%).

d. Kotoran $\left(\mathrm{X}_{3}\right)$ adalah nilai hasil analisis pada PKS dalam satuan (\%).

Tahap analisa data dilaksanakan setelah tahap pengolahan data dilakukan adalah menganalisa hasil perhitungan produksi peramalan regresi linier berganda. Analisa regresi linier berganda yaitu analisis untuk melihat sejauh mana pengaruh Asam Lemak Bebas, Zat Air, dan Zat pengotor dengan IBM SPSS 20.0.

Model regresi linier berganda untuk populasi adalah sebagai berikut:

$$
Y=a+\mathrm{X}_{1}+\mathrm{X}_{2}+\mathrm{X}_{3}
$$

Dimana : $\quad Y=$ Jumlah produksi

$a=$ konstanta

$\mathrm{X}_{1}=$ Asam Lemak Bebas

$\mathrm{X}_{2}=$ Zat Kadar Air

$\mathrm{X}_{3}=$ Zat Pengotor 
Model Summary ${ }^{b}$

\begin{tabular}{|c|c|c|c|c|c|c|c|}
\hline \multirow[t]{2}{*}{ Model } & \multirow[t]{2}{*}{$\mathrm{R}$} & \multirow[t]{2}{*}{ R Square } & \multirow[t]{2}{*}{ Adjusted R Square } & \multirow{2}{*}{$\begin{array}{l}\text { Std. Error of the } \\
\text { Estimate }\end{array}$} & \multicolumn{3}{|c|}{ Change Statistics } \\
\hline & & & & & $\begin{array}{c}\text { R Square } \\
\text { Change }\end{array}$ & F Change & df1 \\
\hline 1 & $.087^{\mathrm{a}}$ & .008 & -.047 & 42819.641 & .008 & .140 & 3 \\
\hline
\end{tabular}

\section{HASIL DAN PEMBAHASAN}

\section{Uji Koefisien Determinasi $\left(\mathbf{R}^{2}\right)$}

Uji koefisien determinasi $R^{2}$ bertujuan untuk mengetahui hubungan antara dua atau lebih variabel denpenden $\left(\mathrm{X}_{1}, \mathrm{X}_{2}, \mathrm{X}_{3}\right)$ terhadap variabel indenpenden $(\mathrm{Y})$ secara bersamaan. Nilai R berkisar antara nol sampai satu.Jika nilai mendekati satu berarti hubungan semakin kuat atau sebaliknya. Jika nilai mendekati nol maka hubungan semakin lemah.

Tabel 1 : Uji Koefisien Determinasi

Model Summary ${ }^{\mathrm{D}}$

\begin{tabular}{|l|r|r|r|}
\hline \multirow{2}{*}{ Model } & \multicolumn{2}{|c|}{ Change Statistics } & \multicolumn{1}{c|}{ Durbin-Watson } \\
\cline { 2 - 4 } & \multicolumn{1}{|c|}{ df2 } & Sig. F Change & \\
\hline 1 & $55^{\mathrm{a}}$ & .936 & 1.833 \\
\hline
\end{tabular}

a. Predictors: (Constant), X3, X1, X2

b. Dependent Variable: $Y$

Berdasarkan Tabel 2 dapat dijelaskan bahwa nilai $\mathrm{R}^{2}$ ( $\mathrm{R}$ Square ) sebesar 0.008 atau $8 \%(0.8)$. Hal ini menunjukkan bahwa persentase secara simultan pengaruh variabel $\mathrm{X}_{1}, \mathrm{X}_{2}, \mathrm{X}_{3}$ yaitu kadar Asam Lemak Bebas, Kadar Zat Air, Kadar Zat Pengotor terhadap variabel denpendent $\mathrm{Y}$ Jumlah produksi $8 \%$ (0.8) sedangkan sisa $98.2 \%$ dipengaruhi oleh variabel lain yang tidak dimasukkan dalam penelitian ini.

Uji $\mathrm{F}$ digunakan untuk mengetahui apakah variabel denpenden $\left(\mathrm{X}_{1}, \mathrm{X}_{2}, \mathrm{X}_{3}\right)$ 
mempengaruhi secara signifikan variabel pengolahan data signifikan simultan. indenpenden $\mathrm{Y}$ yaitu jumlah produksi hasil

Tabel 2 : Uji F

ANOVA $^{\mathrm{a}}$

\begin{tabular}{|rr|r|r|r|r|r|}
\hline Model & & Sum of Squares & Df & Mean Square & F & Sig. \\
\hline & Regression & 768026387.398 & 3 & 256008795.799 & .140 & $.936^{0}$ \\
\cline { 3 - 4 } & Residual & 100843691482.229 & 55 & 1833521663.313 & & \\
& & & & & & \\
& Total & 101611717869.627 & 58 & & & \\
\hline
\end{tabular}

a. Dependent Variable: $Y$

b. Predictors: (Constant), X3, X1, X2

Berdasarkan Tabel 3, hasil diatas diketahui nilai sig untuk pengaruh $\mathrm{X}_{1}, \mathrm{X}_{2}$, $\mathrm{X}_{3}$ terhadap $\mathrm{Y}$ secara simultan sebesar 0.936 $>0.05$; maka Ho diterima dan nilai $\mathrm{F}$ hitung $0.140<\mathrm{F}$ tabel 2.000 sehingga dapat disimpulkan bahwa Hi ditolak. Sehingga dapat dijelaskan hasil nilai sig pengaruh $\mathrm{X}_{1}$, $\mathrm{X}_{2}, \mathrm{X}_{3}$ secara simultan berpengaruh terhadap variabel Y.
Ho = Produksi dapat diterima dan berpengaruh terhadap ALB, Air dan Kotoran.

Hi =Produksi ditolak dan tidakberpengaruh terhadap ALB, Air dan Kotoran.

Uji $F$ digunakan digunakan untuk mengetahui apakah dalam model regresi variabel denpenden $\mathrm{X}_{1}, \mathrm{X}_{2}, \mathrm{X}_{3}$ secara parsial berpengaruh secara signifikan terhadap variabel independen (Y) jumlah produksi. 
Tabel 3 : Uji T

Coefficients $^{\mathrm{a}}$

\begin{tabular}{|c|c|c|c|c|c|}
\hline \multirow[t]{2}{*}{ Model } & \multicolumn{2}{|c|}{ Unstandardized Coefficients } & \multirow[t]{2}{*}{ Standardized Coefficients } & \multirow[t]{2}{*}{$\mathrm{T}$} & \multirow[t]{2}{*}{ Sig. } \\
\hline & B & Std. Error & & & \\
\hline (Constant) & 125372.528 & 441307.929 & & .284 & .777 \\
\hline$X_{1}$ & -24895.778 & 101319.391 & -.035 & -.246 & .807 \\
\hline$X_{2}$ & -579165.558 & 2562728.621 & -.050 & -.226 & .822 \\
\hline$x_{3}$ & 17263814.810 & 31433260.281 & .126 & .549 & .585 \\
\hline
\end{tabular}

Coefficients $^{a}$

\begin{tabular}{|c|c|c|c|c|c|c|}
\hline \multirow[t]{2}{*}{ Model } & \multicolumn{2}{|c|}{$95.0 \%$ Confidence Interval for B } & \multicolumn{3}{|c|}{ Correlations } & \multirow{2}{*}{$\begin{array}{c}\text { Collinearity Statistics } \\
\text { Tolerance }\end{array}$} \\
\hline & Lower Bound & Upper Bound & Zero-order & Partial & Part & \\
\hline \multirow{3}{*}{1} & -759028.325 & 1009773.381 & & & & \\
\hline & -227944.374 & 178152.819 & -.006 & -.033 & -.033 & .903 \\
\hline & -5714988.481 & 4556657.365 & .044 & -.030 & -.030 & .366 \\
\hline$X_{3}$ & -45729846.478 & 80257476.098 & .076 & .074 & .074 & .344 \\
\hline
\end{tabular}

Coefficients $^{\mathrm{a}}$

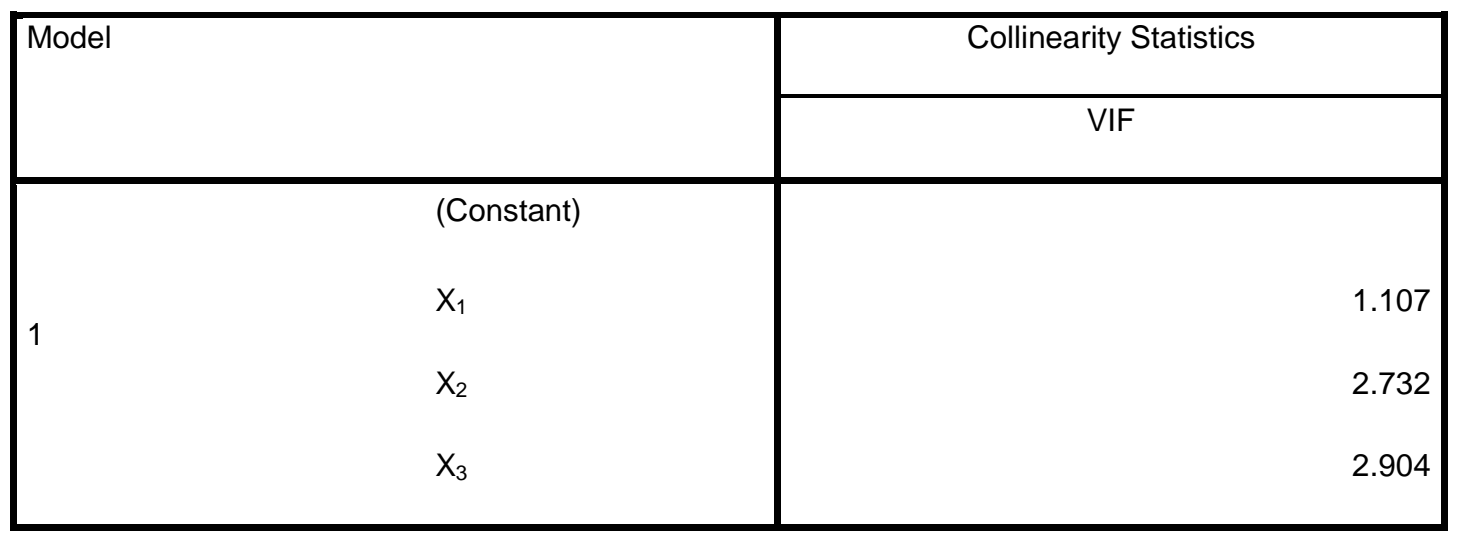

a. Dependent Variable: $Y$ 
Uji hipotesis pertama $\%\left(\mathrm{X}_{1}\right)$ : dik nilai sig, untuk mempengaruhi $\mathrm{X}_{1}$ terhadap $\mathrm{Y}$ adalah sebesar $0.807>0.05$; maka Ho diterima dan nilai $\mathrm{T}$ hitung $-0.246<\mathrm{T}$ tabel 2.000 sehingga dapat disimpulkan bahwa $\mathrm{Hi}$ ditolak makadapat dijelaskan $\%\left(\mathrm{X}_{1}\right)$ pada nilai sig berpengaruh terhadap produksi $(\mathrm{Y})$.

Ho = Produksi dapat diterima dan berpengaruh terhadap ALB, Air dan Kotoran.

$\mathrm{Hi}=$ Produksi ditolak dan tidak berpengaruh terhadap ALB, Air dan Kotoran.

Uji hipotesis pertama \% $\left(\mathrm{X}_{2}\right)$ dik nilai sig, untuk mempengaruhi $\mathrm{X}_{2}$ terhadap $\mathrm{Y}$ adalah sebesar $0.822>0.05$; maka Ho diterima dan nilai $\mathrm{T}$ hitung $-0.226<\mathrm{T}$ tabel 2.000 sehingga dapat disimpulkan bahwa $\mathrm{Hi}$ ditolak maka dapat dijelaskan $\%\left(\mathrm{X}_{2}\right)$ pada nilai sig berpengaruh terhadap produksi $(\mathrm{Y})$.

\section{KESIMPULAN DAN SARAN}

\section{Kesimpulan}

Hasil penelitian ini dengan melakukan penyajian data menggunakan IBM SPSS 20.0 dapat disimpulkan hasil perhitungan regresi linier berganda menyatakan jumlah produksi CPO (Crude Palm Oil) terhadap pengaruh Asam Lemak Bebas, Kadar Zat Air, Kadar Zat Pengotor di PKS PTPN III kebun Aek Nabara Selatan Kecamatan Bilah Hulu. Hal ini menunjukkan hasil derajat yang kuat dan positif mendapatkan nilai 0.8 mendekati 1 hal ini berarti mempunyai pengaruh jumlah produksi CPO (Crude Palm Oil) di PKS PTPN III Kebun Aek Nabara Selatandengan nilai $\mathrm{R}$ Square sebeasar 0.008 dapat di artikan bahwa pengaruh Asam Lemak
Ho = Produksi dapat diterima dan berpengaruh terhadap ALB, Air dan Kotoran.

$\mathrm{Hi}=$ Produksi ditolak dan tidak berpengaruh terhadap ALB, Air dan Kotoran.

Uji hipotesis pertama \% $\left(\mathrm{X}_{3}\right)$ dik nilai sig, untuk mempengarui $\mathrm{X}_{3}$ terhadap $\mathrm{Y}$ adalah sebesar $0.585>0.05$; maka Ho diterima dan nilai $\mathrm{T}$ hitung $0.549<\mathrm{T}$ tabel 2.000 sehingga dapat disimpulkan bahwa Hi ditolak maka dapat dijelaskan $\%\left(\mathrm{X}_{3}\right)$ pada nilai sig berpengaruh terhadap produksi (Y).

$\mathrm{Ho}=$ Produksi dapat diterima dan berpengaruh terhadap ALB, Air dan Kotoran.

$\mathrm{Hi}=$ Produksi ditolak dan tidak berpengaruh terhadap ALB, Air dan Kotoran.

Bebas, Kadar Zat Air, Kadar Zat Pengotor secara bersamaan terhadap jumlah produksi sebesar 8 persen (0.8) sedangkan sisa 98.2 persen dipengaruhi model lain yang tidak dimasukkan dalam penelitian.

\section{Saran}

Penelitian-penelitian lebih lanjut diharapkan selain dapat menganalisis persentase indeks kadar CPO di PKS PTPN III Aek Nabara. Selain itu penelitian lebih lanjut diharapkan dapat menganalisa persentase-persentase yang ada pada kadar CPO seperti vitamin, protein dan lainnya. 
DAFTAR PUSTAKA

Lubis, A.U. 1992. Oil Palm in Indonesia. PlantationResearch Centre, Pematang Siantar.

Mangoensoekarjo, S \& Tojib, A.T. 2008. Manajemen Budidaya Kelapa Sawit. Dalam:Mangoensoekarjo, S.dan Semangun,H.(ed). Manajemen Agribisnis Kelapa Sawit, hal 275279. Gadjah Mada University Press, Yogyakarta.

Pahan, I. 2006. Panduan Lengkap Kelapa Sawit, Manajemen Agribisnis dari Hulu Hingga Hilir. Penebar Swadaya. Jakarta.

Simarmata, L. 1998. Kajian Proses Degumming Minyak Sawit Kasar (Crude Palm Oil) Dengan Menggunakan Asam Sitrat. [Skripsi] Jurusan Teknologi
Industri Pertanian. Institut Pertanian Bogor.

Sipayung, T. 2012. Ekonomi Agribisnis Minyak Sawit. IPB Press : Bogor.

Tim Bina Karya Tani. 2009. Tanaman Kelapa Sawit. CV. Yrama Widya, Bandung

Tim Standarisasi Pengolahan Kelapa Sawit, 1997. PKS Pagar Merbau. repository.usu.ac.id. Diakses pada tanggal 17 September 2012 Pukul $14.00 \mathrm{WIB}$.

Yuwana, H., Lukman., Sidebang, B. 2009. Kajian Benturan Buah Kelapa Sawit (Elaies guinensis) pada Berbagai Permukaan Sebagai Upaya Mengurangi Buah Penyebab Penurunan Kualitas Bahanbaku Pangan. Laporan Penelitian HIBAH Penelitian Strategis Nasional. Fakultas Pertanian, Universitas Bengkulu. Bengkulu. 